\title{
The effect of long-term high-fat diet in ovariectomized Wistar rat on leptin serum levels
}

\author{
Dita Fitriani ${ }^{1}$, Andreanyta Meliala ${ }^{2}$, Denny Agustiningsih ${ }^{2 *}$ \\ ${ }^{1}$ Graduate Student of Basic Medical Science and Biomedical Sciences, Postgraduate \\ Program, ${ }^{2}$ Department of Physiology, Faculty of Medicine, Universitas Gadjah Mada, \\ Yogyakarta, Indonesia.
}

DOI: http://dx.doi.org/10.19106/JMedSci004802201601

\begin{abstract}
Leptin and estrogen have an important role in energy homeostasis through anorexic effects on the central nervous system. These hormones can decrease food intake, increases energy expenditure and thermogenesis. Long-term high-fat diet can lead to impaired leptin function. Moreover, estrogen, deficiency is a risk factor of obesity in menopause. The aim of this study is to investigate the effect of long-term high-fat diet on leptin serum levels in ovariectomized rats. Twenty-eight female Wistar rats (Rattus norvegicus) aged 6-8 weeks with body weight $120-150 \mathrm{~g}$ were used in this study. Rats were divided into 4 groups i.e. OVXSC groups: rat were ovariectomized and given a standard diet; OVXH groups: rat were ovariectomized and given a high-fat diet; SHAMSC groups: rat were not ovariectomized and given a standard diet; SHAMHF groups : rat were not ovariectomized and given a high-fat diet. Pre-post test with control group design for measurement of serum leptin levels, food intake, and Lee index. While post-test only control group design for measurement of abdominal fat mass. Pearson test was used to analyze the correlation between leptin serum levels, food intake, Lee index and abdominal fat mass. Paired t-test was used to analyze the differences between values before and after being treated. The daily food intake dropped in rat fed a high-fat diet although it was not statistically significant $(p>0.05)$. Ovariectomy significantly increase Lee index $(p<0.05)$. Obesity occurs in ovariectomized group, both of high-fat diet and standard diet. Abdominal fat mass was significantly higher in high-fat compared to standard diet group $(p<0.05)$. Increase in levels of serum leptin highest in OVX-HF group $(16.45 \pm 8.75 \mathrm{ng} / \mathrm{mL})$, and the lowest in the SHAM-SC $(2.98 \pm 1.61 \mathrm{ng} / \mathrm{mL})$. In conclusion, serum leptin levels positively correlated with Lee index and abdominal fat mass, but negatively correlated with daily food intake.
\end{abstract}

\section{ABSTRAK}

Leptin dan estrogen memiliki peran penting dalam homeostasis energi melalui efek anoreksigenik pada sistem saraf pusat. Kedua hormon ini dapat menurunkan asupan makan, meningkatkan pengeluaran energi, dan termogenesis. Diet tinggi lemak jangka panjang dapat menyebabkan fungsi leptin terganggu. Selain itu, defisiensi estrogen merupakan faktor risiko terjadinya obesitas pada menopause. Penelitian ini bertujuan mengkaji efek pemberian diet tinggi lemak jangka panjang terhadap kadar leptin serum pada tikus yang diovariektomi. Sebanyak 28 ekor tikus Wistar betina berumur 6-8 minggu dengan berat

$\overline{\text { Corresponding author: denny.agustiningsih@gmail.com }}$ 
120-150 g digunakan dalam penelitian. Tikus dibagi menjadi 4 kelompok, yaitu kelompok tikus ovariektomi dan diberi diet standar (OVX-SC), kelompok tikus ovariektomi dan diberi diet tinggi lemak (OVX-HF), kelompok tikus tidak ovariektomi dan diberi diet standar (SHAM-SC), kelompok tikus tidak ovariektomi dan diberi diet tinggi lemak (SHAM-HF). Penelitian ini menggunakan metode eksperimental murni dengan pre-post test with control group design untuk pengukuran kadar leptin serum, asupan makan dan indeks Lee. Sedangkan post test only control group design untuk massa lemak abdominal. Uji korelasi menggunakan uji Pearson. Uji paired t-test digunakan untuk menganalisis perbedaan nilai sebelum dan setelah diberi perlakuan. Penurunan asupan maka harian dijumpai pada kelompok yang diberi diet lemak tinggi meskipun tidak bermakna $(p>0,05)$. Ovariektomi menyebabkan peningkatan indeks Lee yang bermakna $(p<0,05)$. Obesitas terjadi pada tikus yang diovariektomi baik yang diberi diet tinggi lemak maupun diet standar. Masa lemak abdominal lebih tinggi secara nyata pada kelompok diet tinggi lemak dibandingkan kelompok diet standar $(p<0,05)$. Peningkatan kadar leptin serum tertinggi terjadi pada kelompok OVX-HF $(16,45 \pm 8,75 \mathrm{ng} / \mathrm{mL})$, dan terendah pada SHAM-SC $(2,98 \pm 1,61$ $\mathrm{ng} / \mathrm{mL}$ ). Dapat disimpulkan, kadar leptin serum memiliki korelasi positif dengan indeks Lee dan massa lemak abdominal, namun berkorelasi negatif dengan asupan makan harian.

Keywords: obesity, menopause, leptin, Lee index, abdominal fat.

\section{INTRODUCTION}

Menopause is a critical period in the woman's life related to aging and marks the cessation of the woman's natural reproductive life. During the menopause, the ovaries no longer produce ovum and the production of estrogen decreases and eventually stopped. ${ }^{1}$ The composition of body fat after menopause is changed, from the deposition of subcutaneous fat into the abdominal and visceral fat which causes an increased incidence of metabolic syndrome. This is due to decreased production of estrogen after menopause, which is a crucial factor in influencing metabolic abnormalities. ${ }^{2}$ The estrogen has an anorexigenic function to the central nervous system. When estrogen levels are high, during the estrous cycle or menstruation, as well as during pregnancy decreased food intake and accumulation of subcutaneous fat. In contrast to the ovariectomy, menopause and anti-estrogen therapy increase food intake and abdominal fat. ${ }^{2,3}$

Obesity is the accumulation of excess total body fat leading to high body mass index $\left(\geq 25 \mathrm{~kg} / \mathrm{m}^{2}\right.$ for the Asian population and $\geq 30 \mathrm{~kg} / \mathrm{m}^{2}$ for the European population). Physiologically, obesity can occur because of a disturbance in the energy balance which is the amount of energy intake more than the amount of energy expenditure and the excess energy is stored in the body as fat. ${ }^{4,5}$ The prevalence of obesity in many developed and developing countries have increased and are in an alarming condition, because it has reached pandemic proportions over the past decade. $^{6}$

Leptin is a hormone mainly secreted by white adipose tissue, known as 'satiety hormone'. ${ }^{7}$ Leptin function is as a signaling molecule that communicates messages to the brain about the availability of energy stored in body fat. The brain, particularly the hypothalamus integrates metabolic signals coming from the leptin to regulate energy homeostasis by reducing appetite, increasing energy expenditure and thermogenesis. ${ }^{8,9}$ Women tend to have higher leptin levels than men, but decreased significantly after menopause. ${ }^{9,10}$ In rat Diet-Induced Obese (DIO) with a high-fat feed, leptin resistance can occur. ${ }^{1,11}$ Since estrogen and leptin have 
an important role in energy homeostasis and anorexigenic function, the author interested to investigate the effect of long-term high-fat diet and estrogen deficiency as a risk factor for obesity on leptin function, which is seen through changes in serum leptin levels, daily food intake, Lee index and abdominal fat mass.

\section{MATERIALS AND METHODS}

\section{Animals}

Twenty-eight female Wistar rats (Rattus norvegicus) aged 6-8 weeks with body weight 120-150 g were obtained from Laboratory of Research and Testing Integrated, Universitas Gadjah Mada, Yogyakarta. All of the rats were adapted for seven days in a cage made from plastic material $25 \times 35 \mathrm{~cm}$ in size. Each cage contains a rat and was reposed by chaff and given cover by woven wire. The cages were placed on Animal Treatment Laboratory room which is located in the Department of Physiology, Faculty of Medicine, Universitas Gadjah Mada, Yogyakarta. The temperature ranged $20-25^{\circ} \mathrm{C}$ was under controlled $12 \mathrm{hr}$ of day and night cycle. Standard feed and drinking water were provided in the cages and could be consumed at any time (ad libitum). Protocol of this study was approved by the Medical and Health Research Ethics Committee, Faculty of Medicine, Universitas Gadjah Mada, Yogyakarta.

\section{Animal groupings}

At day $8^{\text {th }}$, rats were randomly divided into two groups. The first goup is ovariectomized rat (OVX) and the second group is not ovariectomized rat (SHAM) with each number of group is 14 rats. After having ovariectomy and undergoing recovery for 21 days, rats in groups of OVX and SHAM were subdivided into two new groups based on the provision of diet. The first group is ovariectomized given standard diet (OVX-SC), the second group is ovariectomized given a high-fat diet (OVX-
HF), the third group is non-ovariectomized given a standard diet (SHAM-SC), and the last group is non-ovariectomized given a high-fat diet (SHAM-HF).

\section{Ovariectomy rat}

Ovariectomy was firstly started by rat anesthesia using ketamine injection 0.2 $\mathrm{mL} / 100 \mathrm{~g}$ body weight (IM) under aseptic conditions. Surgery was begun by doing a small incision on the ventral abdominal wall. After that, ovary was clamped bilaterally and removed out. Uterine horns (the meeting point between the uterus with fallopian tubes) was tied and uterus was left intact, then the abdominal wall was sutured back. In dissected rat (SHAM group), it was anaesthetized and the abdominal wall was opened in the same way as in the ovariectomy ovaries group without removing it out. ${ }^{1}$

\section{Taking and examination of blood samples}

Blood samples for serum leptin levels examination (pre and post-test) was taken from the retro orbital vein of $1.5 \mathrm{~mL}$. Before blood sampling, rats were fasted approximately 6-8 hr. Blood samples were kept frozen for 25 $\mathrm{min}$, then centrifuged $20 \mathrm{~min}$ at $2,000 \mathrm{~g}$, equal to $4,339 \mathrm{rpm}$. Serum was taken and stored at $-20^{\circ} \mathrm{C}$ temperatures until examination using ELISA.

\section{Measurement of daily food intake}

Measurement of food intake was done every day at 8:00 to 10:00 am during the treatment (56 days). The measurement was performed by calculating the difference between the amount of feed given and the remaining amount of feed, both in the feed bowl and scattered in the cage. Feed was given as much as $15 \mathrm{~g} /$ day/rat.

\section{The Lee index}

Naso-anal length and body weight were measured every week during the study (during 
the 8 weeks of administration of a high fat diet). The measurement results are used to calculate the Lee index. Lee index is calculated using the formula, which is the cube root of the weight (g) divided by naso-anal length $(\mathrm{cm})$ and multiplied by 1000 . The result of the calculation is greater than 310 expressed as an indicator of obesity. ${ }^{12}$

\section{Abdominal fat mass extraction and measurements}

Abdominal fat extraction begins with anesthesia using ketamine $0.2 \mathrm{~mL} / 100 \mathrm{gBW}$ (IM), under aseptic conditions. Surgery was performed through an incision of the ventral abdominal wall. After the abdominal wall was open, then intra-abdominal fat was collected including retroperitoneal and omental fat. Collected fat was weighed on digital scales and expressed in units of grams.

\section{Statistical analysis}

Normality data test with the Shapiro-Wilk test and variance data test were using Levene test. Normal distribution data was shown as mean \pm standard deviations. Parametric statistical tests for numerical data was done by using one-way ANOVA, followed by multiple comparison post hoc LSD $(p<0.05)$. Correlation between serum leptin levels, food intake, Lee index and abdominal fat mass was tested using Pearson correlation test. Paired t-test (for daily food intake, Lee index and leptin serum levels) or the Wilcoxon signed rank test (for daily food intake OVX-HF group) was used to analyze the differences in values before and after being treated.

\section{RESULTS}

\section{The daily food intake}

The highest daily food intake was found in OVX-SC group $(9.71 \pm 1.40 \mathrm{~g})$ and the lowest was in the SHAM-HF group $(6.68 \pm 0.78 \mathrm{~g})$. The statistical analysis showed a significant difference between the first week and eighth week of the SHAM-SC group, whereas in OVX-SC, OVX-HF and SHAM-HF groups were not found any significant differences (FIGURE 1).

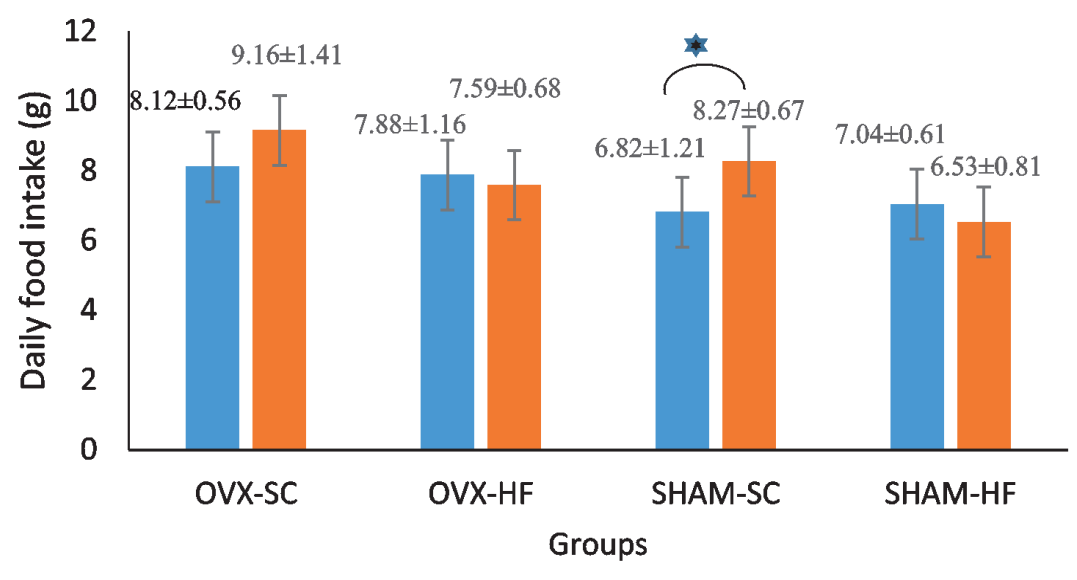

Week 1 Week 8

FIGURE 1. The bar chart is the average daily food intake \pm standard deviation in the first week and the last week giving a high-fat diet. OVXSC: groups of rat were ovariectomized given a standard diet; OVXHF: groups of rat were ovariectomized given a high-fat diet; SHAMSC: groups of rat were not ovariectomized given a standard diet; SHAMHF: groups of rat were not ovariectomized given a high-fat diet. The results of paired t-test were significantly marked by $(*)$ 


\section{Lee Index}

Lee index value in each treatment group in this research is shown on FIGURE 2.

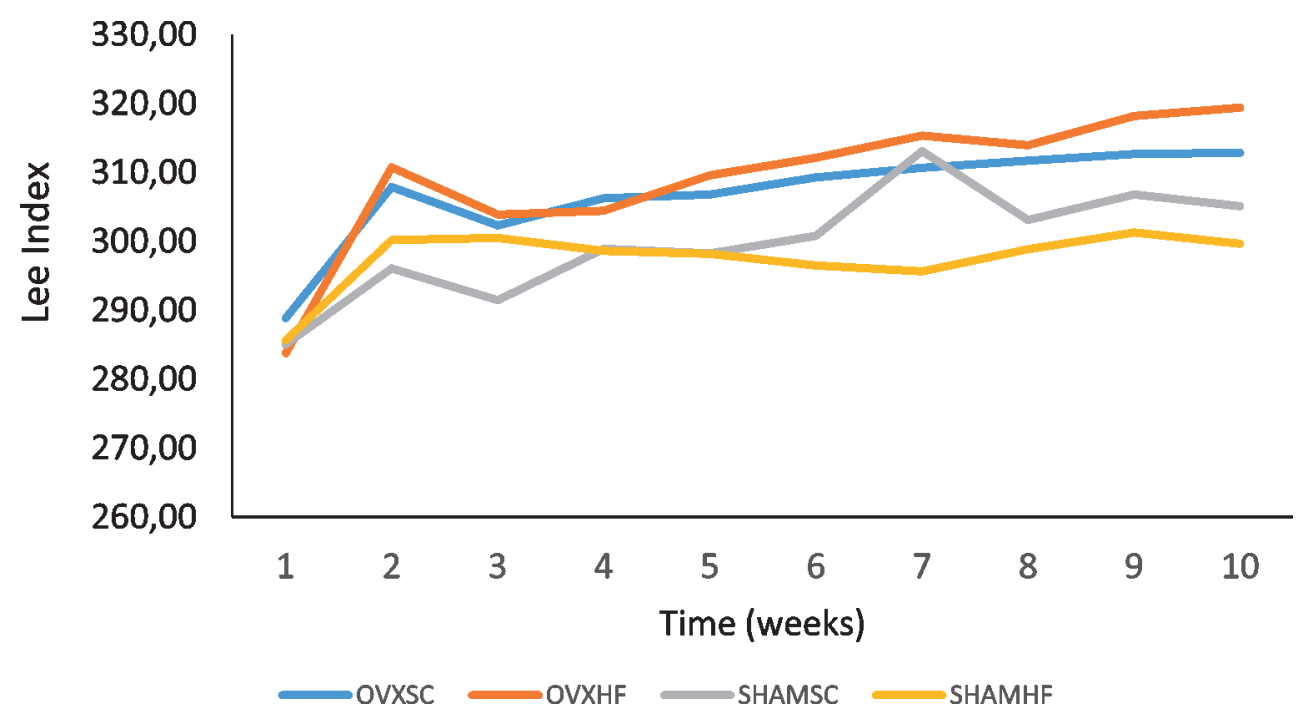

FIGURE 2. First week to eighth week Lee index graph of diet treatment in each group. OVXSC: groups of ovariectomized rat and given a standard diet; OVXHF: groups of ovariectomized rat and given a high-fat diet; SHAMSC: groups of non ovariectomized rat and given a standard diet; SHAMHF: groups of non ovariectomized and given a high-fat diet.

The results of paired t-test on the mean well as before and after giving high-fat diet of Lee index before and after ovariectomy, as are shown in the TABLE 1.

TABLE 1. The mean \pm standard deviation Lee index before ovariectomy, after ovariectomy and after givin high fat diet based on group

\begin{tabular}{cccc}
\hline \multirow{3}{*}{ Group (n=7) } & \multicolumn{3}{c}{ Lee Index } \\
\cline { 2 - 4 } & $\begin{array}{c}\text { Beginning (before } \\
\text { ovariectomy) }\end{array}$ & $\begin{array}{c}\text { After Ovariectomy (before } \\
\text { given high fat diet) }\end{array}$ & $\begin{array}{c}\text { End (After given } \\
\text { high fat diet) }\end{array}$ \\
\hline OVX-SC & $288.88 \pm 16.48^{\mathrm{a}}$ & $307.86 \pm 5.56^{\mathrm{a}}$ & $312.84 \pm 6.94$ \\
OVX-HF & $283.78 \pm 6.19^{\mathrm{b}}$ & $310.75 \pm 6.21^{\mathrm{b}}$ & $319.38 \pm 8.23^{\mathrm{b}}$ \\
SHAM-SC & $285.03 \pm 7.33^{\mathrm{c}}$ & $296.05 \pm 6.56^{\mathrm{c}}$ & $305.12 \pm 4.37^{\mathrm{c}}$ \\
\hline
\end{tabular}

Description: OVXSC: ovariectomy group and given a standard diet; OVXHF: ovariectomy group and given a high-fat diet; SHAMSC: non-ovariectomy group and given a standard diet; SHAMHF: non-ovariectomy group and given a high-fat diet; Paired t-test results were significantly $(p<0.05)$ marked by the same letter notation. 


\section{Abdominal fat mass}

The mean value of abdominal fat mass in each group after treatment from the highest to the lowest, the OVX-HF group $(10.49 \pm 3.79$ g), SHAM-HF group (10.04 $\pm 1.60 \mathrm{~g})$, OVXSC group $(7.31 \pm 2.76 \mathrm{~g})$ and SHAM-SC group $(6.08 \pm 2.41 \mathrm{~g})$ are shown in FIGURE 3.

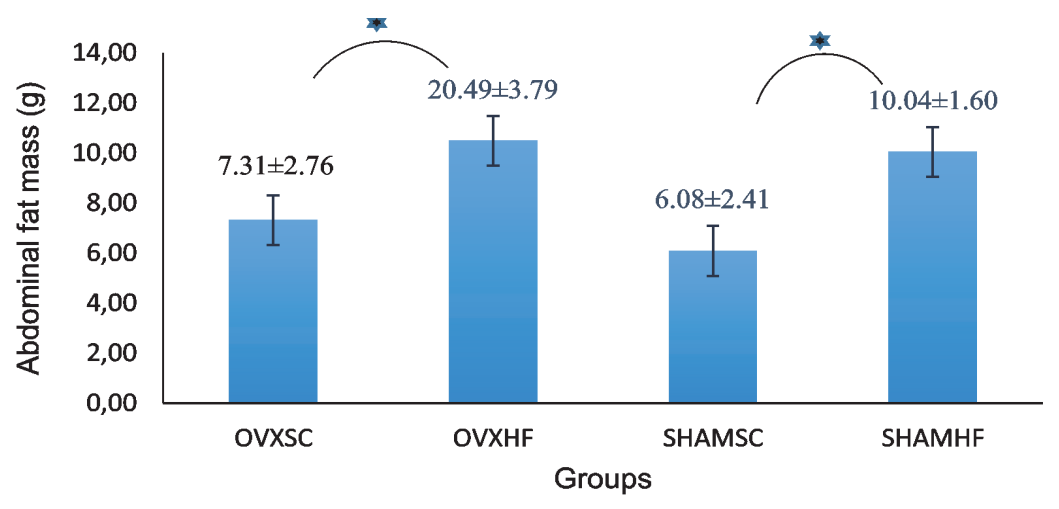

FIGURE 3. The bar chart abdominal fat mass mean \pm standard deviation after treatment. OVXSC: ovariectomy group and given a standard diet; OVXHF: ovariectomy group and given a high-fat diet; SHAMSC: non ovariectomy group and given a standard diet; SHAMHF: non ovariectomy group and were given a high fat diet. Significant differences between groups are marked by $(*)$

\section{Levels of serum leptin}

The mean value of leptin serum levels before and after treatment is shown in FIGURE 4. The highest increased serum leptin levels was in OVX-HF group with an average value increase of $16.45 \pm 8.75 \mathrm{ng} / \mathrm{mL}$, and the lowest was in SHAM-SC group (2.98 $\pm 1.61 \mathrm{ng} / \mathrm{mL}$ ).

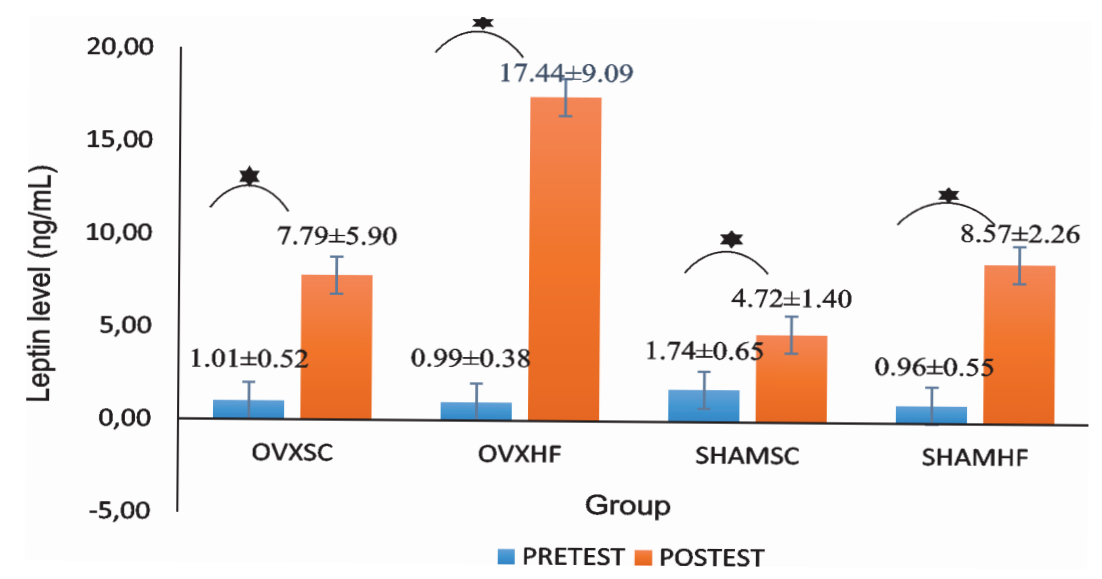

FIGURE 4. The bar chart serum leptin levels mean \pm standard deviation before and after treatment. OVXSC: ovariectomy group and given a standard diet; OVXHF: ovariectomy group and given a high-fat diet; SHAMSC: non ovariectomy group and given a standard diet; SHAMHF: non ovariectomy group and given a high fat diet. An asterisk $(*)$ indicate a significant difference. 


\section{DISCUSSION}

The daily food intake dropped in rat fed a high-fat diet (OVX-HF and SHAMHF groups), but this reduction was not statistically significant. These results were different from previous research by Lin et $a l .{ }^{11}$ which explained the food intake in rat fed a high-fat diet was higher than rat fed a standard diet since the $8^{\text {th }}$ week after given a high fat diet. A decreasing daily food intake in OVX-HF group is because the effect of leptin, seen from the increase in leptin serum levels were very high $(16.45 \pm 8.75 \mathrm{ng} / \mathrm{mL})$. Leptin is a hormone that plays a role in energy homeostasis and have anorexigenic effects on the central nervous system. ${ }^{9}$ Leptin circulation are transported to the brain, binds to the leptin receptor $(\mathrm{ObRb})$ in the hypothalamus, activates the JAK-STAT3 pathway and lead to suppression orexigenic neuropeptides such as Neuropeptide $Y$ (NPY) and agoutirelated protein (AgRP), which plays a role in increasing food intake. In addition, activation of JAK-STAT3 results in increased production of anorexigenic neuropeptides as Proopiomelanocortin (POMC) and Cocaine and Amphetamine-regulated Transcript (CART), which plays a role in reducing food intake. ${ }^{13,14}$

A decreasing daily food intake in SHAMHF group probably caused by the effects of the hormone estrogen. Estrogen acutely and chronically affecting energy homeostasis through inhibitory effects on food intake involving estrogen receptors (ERs) in the central nervous system. Estrogen also trigger an increase in the number of input stimulation to the POMC neurons in the ARC hypothalamus that produce anorexigenic neuropeptides. ${ }^{15-17}$

LSD posthoc analysis of the results showed that the difference in daily food intake between first week and the eight week was higher in the SHAM-SC compared with the SHAM-HF group. These results indicate that the high-fat diet only influence the nonovariectomized group. The low daily food intake in SHAM-HF group can be caused by the effects of leptin as an inhibitor of orexigenic neuropeptides. ${ }^{1}$ Another possibility is because of the content of saturated fatty acids in the diet which is an important factor in the energy balance. Although the daily food intake on SHAM-HF group is low, but the daily energy intake is relatively higher than that given a standard diet. This is because of the high energy content of fat in the diet. Moreover, fat also has the highest nutrient utilization efficiency compared to carbohydrates or protein, so the adequacy of energy intake is achieved faster even though fewer. ${ }^{1,12}$

OVX-SC group has an increasing daily food intake, but this increase was not statistically significant. An increase of daily food intake in the group of OVX-SC is probably caused by the influence of estrogen deficiency due to ovariectomy. Estrogen has an effect on food intake similar to leptin, and giving exogenous estrogen causes a decrease of food intake in ovariectomized rat. ${ }^{18}$ Estrogen is also known have a role in the regulation of orexigenic neuropeptides such as NPY and grelin, and anorexigenic neuropeptides like insulin, leptin and serotonin. ${ }^{19}$ In addition, studies reveals that estrogen deficiency causes excessive production of NPY in the hypothalamus and central leptin sensitivity disorders that causes an increase food intake and contributes to obesity. ${ }^{15}$

The results of paired t-test showed that there was a significant increase in the value of the index Lee before and after ovariectomy both in ovariectomy and non ovariectomy group. These results indicated that the increase in the Lee index in rat was not only influenced by estrogen deficiency. Estrogen deficiency that occurs at menopause has been shown to 
closely related with an increase of women body mass, meanwhile estrogen withdrawal through ovariectomy in rat can increase body mass and this condition can be balanced by estradiol therapy. ${ }^{13,20}$ Another study ${ }^{21}$ also explains that the decline in estrogen levels along menopause is accompanied by weight gain, and a decrease in energy expenditure. But there are other factors that also affect the increase in body mass index in addition to estrogen deficiency. Several factors affect the body mass index in adults including the amount and composition of food consumed, age, physical activity, a decrease in the body's metabolic or physiological changes related to menopause in women which enables an increase in body weight. ${ }^{22}$ Another study explains that obesity is especially common in women, increased with age, and is closely related to the frequency of consumption and the amount of calories in food. ${ }^{23}$ From the described studies, it is known that increasing age has an influence on an increase in body mass index, especially in women. It is associated with a decrease in the body's metabolism and physical activity which causes an increase in body mass index is easier to rise. ${ }^{23}$

In this study, physical activity in rat could be assumed to be very low. The small size of cage $(25 \times 35 \mathrm{~cm})$ caused the limited activity of rat, so there is no excessive energy expens. In addition, the availability and adequacy of feed given to the rat also could be factor influencing the increase in body mass index. Food and drink were always available inside the enclosure allowing the rat to consume at any time. Positive energy balance, when energy intake more than energy expenditure can cause an increase in body mass index and obesity. $^{4}$

In the SHAM-HF group was no increase in the Lee index after a fat diet. Oppositely, the Lee index decreased mean of $0.57 \pm 7.20$, but this reduction was not statistically significant $(p=0.840)$. The reduction of Lee index in SHAM-HF group was likely because the effect of anorexigenic estrogen. Estrogen is a steroid hormone that acts directly or indirectly in reducing food intake, increase energy expenditure and termogenesis. ${ }^{15}$ Estrogen is also suspected as a modulator of the anabolic action of leptin. High estrogen levels are associated with increased sensitivity of leptin central characterized by high expression of the leptin receptor $(\mathrm{ObRb})$ in the arcuate nucleus (ARC) despite circulating leptin levels are not increased. ${ }^{13,24}$ The reduction of Lee index in SHAM-HF group may also be caused by the influence of leptin. Brown et al., ${ }^{15}$ explains that leptin in circulation will be transported to the brain, then leptin will bind to the leptin receptor $(\mathrm{ObRb})$ in the hypothalamus. The bond between leptin and its receptor causes activation of JAK/STAT which will trigger the production of anorexigenic neuropeptides and inhibit orexigenic neuropeptides. Anorexigenic neuropeptides activation causes a decrease in appetite, increased energy expenditure and thermogenesis. ${ }^{10,15}$ The effect of anorexigenic neuropeptides which may indirectly lead to decrease on the Lee index in SHAM-HF group.

Examination of abdominal fat mass after treatment in this study showed no significant difference between in both the ovariecvatomized and non-ovariectomized group. The differences appeared only among the group given high-fat diet and a standard diet, which was between OVX-HF and OVXSC groups and between SHAM-HF and SHAM-SC groups, which indicated that the differences caused by the provision of highfat diet and it was not because of the effect of ovariectomy. These results are in contrast to some previous researches which explained that menopausal women and ovariectomized 
rat is accompanied by changes in energy homeostasis which leads to increased intraabdominal fat mass. ${ }^{24-26}$ However another study $^{27}$ described a similar result to this research. Ovariectomy in rat and menopause that occurs in women, both are closely linked with increase body mass and total fat mass. But in ovariectomy, more fat will be stored in the subcutaneous compared to intra-abdominal.

The results showed that the group given a high-fat diet, having a mean abdominal fat mass, was higher than those given a standard diet. This is probably caused by the content of saturated fatty acids that existed in a high-fat diet. Studies in humans and animals showed that saturated fatty acids are more obesogenic than unsaturated fatty acids. It is because very little saturated fatty acids are used for energy and mostly stored in adipose tissue as triacylglycerols. ${ }^{12,28}$

Increased levels of leptin serum was significant in the control group (SHAM-SC) that are likely due to the indirectly influence of estrogen. ${ }^{29}$ Studies explain that leptin levels may be influenced by estrogen, either directly or indirectly, through changes in body weight. In addition, high levels of estrogen are closely linked to improved leptin central sensitivity in rodents. ${ }^{30,31}$ Other possibility that causes increase leptin levels in SHAM-SC group is subcutaneous fat produce more leptin than the visceral fat. ${ }^{13}$

Ovariectomy and high-fat diet in this study affected serum leptin levels, seen from the significant differences between OVX-SC and OVX-HF group, and between OVX-HF and SHAM-HF group. The results agreed with previous research suggesting that highfat diet given to ovariectomized rat may lead to increased leptin serum levels which are higher than non-ovariectomized rat and with standard diet. ${ }^{1}$ Another study ${ }^{32}$ explains that there are some things that can affect changes in circulating leptin levels, such as changes in body weight, fasting and high-fat diet.

Increased serum leptin levels positively correlated with increased Lee index and abdominal fat mass, but negatively correlated with daily food intake. This indicates that the high-fat diet given to ovariectomized or non-ovariectomized rat still heve not been able to induce leptin resistance. In humans or even obese rat, leptin resistance is commonly found. Leptin resistance is a condition that indicates a decrease in the response to leptin and linked as compensation for increased levels of circulating leptin which takes place continuously in subjects with obesity. ${ }^{10,14}$ But in this study, there was no leptin resistance in obese group which was categorized based on the average value of the Lee index (groups of rats OVX-SC and OVX-HF), It was due to high levels of leptin but low of daily food intake.

Meanwhile, the positive correlation between elevated levels of serum leptin with Lee index and abdominal fat mass in this study have met with previous research that suggests that circulating leptin consentration is correlated with body mass index (BMI), fat percentage and total body fat mass. ${ }^{33-35}$

\section{CONCLUSIONS}

Overall, high-fat diet in ovariectomized rats is a risk factor for obesity and impaired function of the hormone leptin. High-fat diet in ovariectomized rats leads to an increase in body mass index, abdominal fat mass and serum leptin levels, and a decrease in daily food intake which indicates that leptin resistance does not occur in this study.

Further research is needed to determine the effect of high-fat diet in ovariectomized rats for leptin seen through molecular substances or neuropeptides in the central nervous system 
such as SOCS-3, STAT3 and NPY in order to explain the mechanism of the leptin resistance on the subject of obesity.

\section{ACKNOWLEDGEMENTS}

The author is thankful to the Study Program of Basic Medical and Bomedical Sciences, Postgraduate Program, Faculty of Medicine, lecturers and Physiology staff at Universitas Gadjah Mada for the advice and favor.

\section{REFERENCES}

1. Correia AL Jr, Aguila MB, Mandarim-deLacerda CA, Faria TS. Effects of high-fat diet on plasma lipids, adiposity, and inflammatory markers in ovariectomized C57BL/6 mice. Nutrition 2012; 28(3):316-23. http://dx.doi. org/10.1016/j.nut.2011.07.014

2. Yonezawa R, Wada T, Matsumoto N, Morita $\mathrm{M}$, Sawakawa K, Ishii Y, et al. Central versus peripheral impact of estradiol on the impaired glucose metabolism in ovariectomized rat on a high-fat diet. Am J Physiol Endocrinol Metab 2012; 303(4):445-56. http://dx.doi. org/10.1152/ajpendo.00638.2011

3. Roepke TA. Oestrogen modulates hypothalamic control of energy homeostasis through multiple mechanisms. J Neuroendocrinol 2009; 21(2):14150. http://dx.doi.org/ 10.1111/ j.13652826.2008.01814.x

4. Margetic S, Gazzola C, Pegg GG, Hill RA. Leptin: a review of its peripheral actions and Interactions. Int J Obes Relat Metab Disord 2002; 26(11):1407-33.

5. Mushref MA, Srinivasan S. Effect of high fatdiet and obesity on gastrointestinal motility. Ann Transl Med 2013; 1(2):14.

6. Boonyaratanakornkit V, Pateetin P. The role of ovarian sex steroids in metabolic homeostasis, obesity, and postmenopausal breast cancer: molecular mechanisms and therapeutic implications. Biomed Res Int 2015;149196:114. http://dx.doi.org/ 10.1155/2015/140196.

7. Paracchini V, Pedotti P, Taioli E. Genetics of leptin and obesity: a HuGE review. Am J Epidemiol 2005; 162(2):101-14. http:// dx.doi.org/10.1093/aje/kwi174

8. Morris DL, Rui L. Recent advances in understanding leptin signaling and leptin resistance. Am J Physiol Endocrinol Metab 2009; 297(6):1247-59. http://dx.doi. org/10.1152/ajpendo.00274.2009

9. Kelesidis T, Kelesidis I, Chou S, Mantzoros CS. Narrative review: the role of leptin in human physiology: emerging clinical applications. Ann Intern Med 2010; 152(2):92100. http://dx.doi.org/10.7326/0003-4819152-2-201001190-00008

10. Dardeno TA, Chou SH, Moon HS, Chamberland JP, Fiorenza CG, Mantzoros CS. Leptin in human physiology and therapeutics. Front Neuroendocrinol 2010; 31(3):377-93. http://dx.doi.org/10.1016/j. yfrne.2010.06.002.

11. Lin S, Thomas TC, Storlien LH, Huang XF. Development of high fat diet-induced obesity and leptin resistance in C57B1/6J mice. Int J Obes Relat Metab Disord 2000; 24(5):63946. http://dx.doi.org/10.1038/sj.ijo.0801209

12. Hariri N, Thibault L. High-fat diet-induced obesity in animal models. Nutr Res Rev 2010; 23(2):270-99. http://dx.doi.org/10.1017/ S0954422410000168

13. Park HJ, Ahima RS. Physiology of leptin: energy homeostasis, neuroendocrine function and metabolism. Metabolism 2015; 64(1):24-34. http://dx.doi.org/10.1016/ j.metabol.2014.08.004

14. Ahima RS. Revisiting leptin's role in obesity and weight loss. J Clin Invest 2008; 118(7):2380-3. http://dx.doi.org/10.1172/ JCI36284 
15. Brown LM, Clegg DJ. Central effects of estradiol in the regulation food intake, body weight, and adiposity. J Steroid Biochem Mol Biol 2010; 122(1-3):65-73. http://dx.doi. org/10.1016/j.jsbmb.2009.12.005

16. Gao Q, Mezei G, Nie Y, Rao Y, Choi CS, Bechmann I, et al. Anorectic estrogen mimics leptin's effect on the rewiring of melanocortin cells and Stat3 signaling in obese animals. Nat Med 2007; 13(1):89-94. http://dx.doi. org $/ 10.1038 / \mathrm{nm} 1525$

17. Gao Q, Horvath TL. Cross-talk between estrogen and leptin signaling in the hypothalamus. Am J Physiol Endocrinol Metab 2008; 294(5):E817-26.

http://dx.doi.org/10.1152/ajpendo.00733. 2007

18. Pelleymounter MA, Baker MB, McCaleb M. Does estradiol mediate leptin's effects on adiposity and body weight? Am J Physiol 1999; 276(5 Pt 1):955-63.

19. Fungfuang W, Terada M, Komatsu N, Moon C, Saito TR. Effects of estrogen on food intake, serum leptin levels and leptin mRNA expression in adipose tissue of female rats. Lab Anim Res 2013; 29(3):168-73. http:// dx.doi.org/ 10.5625/lar.2013.29.3.168

20. Chen Y, Heiman ML. Increased weight gain after ovariectomy is not a consequence of leptin resistance. Am J Physiol Endocrinol Metab 2001; 280(2):E315-22.

21. Bryzgalova G, Lundholm L, Portwood $\mathrm{N}$, Gustafsson J, Khan A, Efendic S,et al. Mechanisms of antidiabetogenic and body weight-lowering effects of estrogen in highfat diet-fed mice. Am J PhysiolEndocrinol Metab 2008; 295(4):E904-12. http://dx.doi. org/10.1152/ajpendo.90248.2008

22. Asil E, Surucuoglu MS, Cakiroglu FP, Ucar A, Ozcelik AO, Yilmaz MV, et al. Factors That affect body mass index of adults. J Nutr 2014; 13(5):255-60.

http://dx.doi.org/10.3923/pjn.2014.255.260
23. Fouad M, Rastam S, Ward K, Maziak W. Prevalence of obesity and its associated factors in Aleppo, Syria. Prev Control 2006; 2(2):85-94. http://dx.doi.org/10.1016/j. precon.2006.09.001

24. Jarvis FM, Clegg DJ, Hevener AL. The role of estrogens in control of energy balance and glucose homeostasis. Endocr Rev 2013; 34(3):309-38. http://dx.doi.org/10.1210/ er.2012-1055

25. Carr MC. The emergence of the metabolic syndrome with menopause. J Clin Endocrinol Metab 2003; 88(6):2404-11. http://dx.doi. org/10.1210/jc.2003-030242

26. Toth MJ, Tchernof A, Sites CK, Poehlman ET. Effect of menopausal status on body composition and abdominal fat distribution. Int J Obes 2000; 24(2):226-31. http://dx.doi. org/10.1038/sj.ijo.0801118

27. Gloy V, Langhans W, Hillebrand JJ, Geary $\mathrm{N}$, Asarian L. Ovariectomy and overeating palatable, energy dense food increase subcutaneous adipose tissue more than intra-abdominal adipose tissue in rats. Biol Sex Differ 2011; 2:6. http://dx.doi. org/10.1186/2042-6410-2-6

28. Storlien LH, Huang XF, Lin S, Xin X, Wang HO, Else PL, Dietary fat subtypes and obesity. World Rev Nutr Diet 2001; 88:148-54. http:// dx.doi.org/10.1159/000059778

29. Pinilla L, Seoane LM, Gonzalez L, Carro E, Aguilar E, Casanueva FF, et al. Regulation of serum leptin levels by gonadal function in rats. Eur J Endocrinol 1999; 140(5):468-73. http://dx.doi.org/10.1530/eje.0.1400468

30. Bennett PA, Lindell K, Wilson C, Carlsson LM, Carlsson B, Robinson IC. Cyclical variations in the abundance of leptinreceptors, but not in circulating leptin, correlate with NPY expression during the oestrous cycle. Neuroendocrinology 1999; 69(6):417-23. http://dx.doi.org/10.1159/000054444 
31. Ainslie DA, Morris MJ, Wittert G, Turnbull H, Proietto J, Thorburn AW. Estrogen deficiency causes central leptin insensitivity and increased hypothalamic neuropeptide Y. Int J Obes 2001; 25(11):1680-8. http://dx.doi. org/10.1038/sj.ijo.0801806

32. Weigle DS, Duell PB, Connor WE, Steiner RA, Soules MR, Kuijper JL. Effect of fasting, refeeding, and dietary fat restriction on plasma leptin levels. J Clin Endocrinol Metab 1997; 82(2):561-5.http://dx.doi.org/10.1210/ jcem.82.2.3757

33. Kobayashi J, Sasaki T, Watanabe M. The relationship of abdominal fat mass assessed by helical or conventional computed tomography to serum leptin concentration. J Atheroscler Thromb 2004; 11(3):173-9. http://dx.doi.org/10.5551/jat.11.173

34. Paul RF, Hassa M, Nazar HS, Gillani S, Afzal N, Qayyum I. Effect of body mass index on serum leptin levels. J Ayub Med Coll Abbottabad 2011; 23(3):40-3.

35. Considine RV, Sinha MK, Heiman ML, Kriaugiunas A, Stephens TW, Nyce MR, et al. Serum immunoreactive-leptin concentration in normal weight and obese humans. N Engl J Med 1996; 334(5):292-5. http://dx.doi. org/10.1056/NEJM199602013340503 